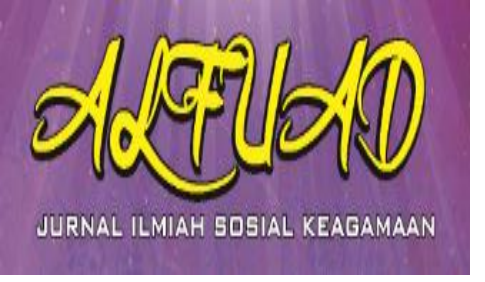

\author{
ALFUAD JOURNAL, 2 (2), 2018, (92-106) \\ (Print ISSN 2614-4786) \\ Available Online at \\ http://ecampus.iainbatusangkar.ac.id/ojs/index.php/alfuad
}

\title{
KOMUNIKASI PEMASARAN USAHA KULINER DI KOTA PEKANBARU
}

\section{Oktri Permata Lani*) \\ Institut Agama Islam Negeri Batusangkar Indonesia \\ E-mail: \\ oktripermatalani@iainbatusangkar.ac.id}

\section{Ilham Havifi}

Universitas Andalas

Indonesia

E-mail: ilham_havifi@yahoo.com

*) Corresponding Author

\begin{abstract}
The city of Pekanbaru is a strategic area where the population is increasing and becoming a metropolitan city. The rapid development of Pekanbaru City is also reflected in the rapid growth of businesses in various places, with various business sectors. One of the most prominent efforts is the business in the culinary field. Almost in every corner of the culinary business available in the city of Pekanbaru with a variety of culinary choices. The great desire of culinary entrepreneurs in the city of Pekanbaru in carrying out their business, maintaining, developing to become bigger and then reaching the peak. In this case, three culinary ventures in Pekanbaru, namely Martabak Djoeragan, Mini Chef and Waroenk Baper, require marketing communication in the introduction of their culinary business to the community, not only as an introduction but also to maintain the existence of their business. This study uses quality methods. The results of this study indicate that the clinical marketing communication of the clinicians in Pekanbaru through advertising activities, sales promotion activities, public relations and public relations activities, personal sales activities, direct marketing activities, event activities and experiences. Besides marketing communication is also associated with brand equity, which is seen from brand awareness and response to the brand. The use of New Media is very important in maintaining, introducing, and developing its business.
\end{abstract}

Keywords: Marketing Communication, UMKM, New Media

\section{PENDAHULUAN}

Menurut data yang diperoleh oleh peneliti jumlah UMKM di kota Pekanbaru menjadi jumlah terbanyak dibandingkan dengan jumlah UMKM di kabupaten/kota lainnya di Riau. Data dinas koperasi (diskop) dan UKM Riau menyebutkan bahwa Pekanbaru dengan 68. 728 UMKM-nya menempati posisi pertama dalam jumlah
UMKM. Posisi kedua adalah Kampar dengan jumlah UMKM-nya sebanyak 45. 446 UMKM. Inhil dengan 44.891 UMKM menempati posisi ketiga.

$$
\text { Selanjutnya, Bengkalis (42.029), }
$$

Rohil (34.036 UMKM), Rohul (27.074 UMKM), Inhu (26.488 UMKM), Siak (22.948 UMKM), Kuansing (21.450 UMKM), Dumai (20. 782 UMKM), dan 
Palalawan dengan 13. 824 UMKM-nya menempati posisi juru kunci (ukmriau.com, 24/09/2016: 19.00). Perkembangan ini dapat di lihat dengan jumlah pengusaha kuliner di kota Pekanbaru semakin bertambah dari tahun ke tahun. Hal itu disebabkan oleh ketergiuran para masyarakat, untuk mengubah ekonomi mereka. Salah satunya dengan cara membuka usaha kuliner.

Menurut data yang di peroleh oleh penulis dari sejumlah UMKM yang tersebar di seluruh kabupaten/kota seluruh Riau itu, adalah sektor perdagangan dengan jumlah 77.156 UMKM menjadi sektor paling diminati dibandingkan dengan jasa (19.656 UMKM), produksi (12.760) dan industri dengan 11.320 UMKM-nya. Dalam sektor perdagangan ini termasuk di dalamnya bidang kuliner (ukmriau.com, 24/09/2016: 20.00).

Salah satu usaha kuliner yang sempat dan bahkan sedang ramai diperbincangkan adalah usaha kuliner Martabak Djoeragan, Mini Chef dan terakhir Waroenk Baper. Ketiga usaha kuliner ini merupakan kuliner yang menjadi perbincangan masyarakat luas di Kota Pekanbaru. Namun begitu ketiga usaha kuliner ini menawarkan sajian kuliner yang berbeda antara satu sama lainnya.

Usaha kuliner Martabak Djoeragan merupakan usaha kuliner yang menyajikan martabak dengan pilihan menu lengkap serta toping menarik. Usaha kuliner Martabak Djoeragan ini sudah berdiri hampir empat tahun di Kota Pekanbaru. Di awal munculnya usaha kuliner Martabak Djoeragan di Kota Pekanbaru mendapatkan tanggapan yang begitu positif dari masyarakat Kota Pekanbaru. Hal ini dapat di lihat dengan ramainya pembelian yang di lakukan oleh masyarakat Kota Pekanbaru.

Dengan banyaknya peminat usaha kuliner Martabak Djoeragan di Kota Pekanbaru membuatnya mampu membuka lima cabang yang tersebar di seluruh Kota Pekanbaru di luar cabang Kota Duri dan bahkan pada bulan Oktober tahun 2016 ia juga kembali membuka cabang di Kota Padang. Namun begitu di saat memulai keberhasilannya, muncul beberapa usaha kuliner yang begitu mirip dengan sajian usaha kulinernya. Hal ini terjadi pada tahun 2016, munculnya banyak pesaing seperti Martabak Om Ndut, Martabak Mandor dan banyak lainnya membuat usaha kuliner Martabak Djoeragan masih harus melakukan komunikasi pemasaran. Usaha kuliner Martabak Djoeragan sudah dapat di katakan sebagai usaha kuliner yang cukup lama. Tetapi ia masih menggunakan komunikasi pemasaran sebagai cara yang jitu untuk dapat mempertahankan usahanya dari saingan para kompetitornya.

Bagi usaha yang akan berkembang komunikasi pemasaran juga sangat berperan penting. Mengapa tidak, usaha kuliner yang sedang akan berkembang membutuhkan banyak minat dari seluruh masyarakat Kota 
Pekanbaru. Usaha kuliner Mini Chef merupakan usaha kuliner yang sudah berdiri sekitar sembilan bulan dan menyajikan makanan khas Korea yang satu-satunya di Kota Pekanbaru menyediakan menu Korea yang sangat lengkap. Usaha Mini Chef ini sangat membutuhkan komunikasi pemasaran dalam membantu dalam hal pengembangan usahanya. Komunikasi pemasaran yang nantinya di lakukan oleh usaha kuliner Mini Chef dapat menambah pengetahuan masyarakat Kota Pekanbaru dan membuat pengunjung di Mini Chef semakin bertambah dari hari ke harinya. Keinginan setiap usaha yang akan berkembang pasti menginginkan usahanya memperlihatkan prospek yang baik.

Begitu pula dengan usaha kuliner yang baru akan memulai. Seperti usaha kuliner Waroenk Baper Pekanbaru yang mana merupakan usaha yang sedang hangatnya diperbincangkan oleh para masyarakat Kota Pekanbaru. Pihak usaha kuliner Waroenk Baper juga melakukan komunikasi pemasaran dalam pengenalan usaha kuliner yang ia geluti kepada masyarakat luas Kota Pekanbaru. Dari ketiga usaha kuliner tersebut dapat di katakan baik usaha yang cukup bisa di katakan lama, usaha yang akan mulai berkembang bahkan usaha yang baru memulai di usaha kuliner, sangatlah membutuhkan komunikasi pemasaran sebagai bentuk cara pihak pengusaha dapat mencapai target, tujuan dan sasaran yang diinginkan masing-masing. Namun walaupun ketiga usaha ini melakukan komunikasi pemasaran tapi tidak dapat menggunakan komunikasi pemasaran yang tepat akan membuat usahanya kandas di tengah jalan karena dapat di gantikan oleh usaha-usaha kuliner yang bermunculan serta tidak dapat melihat keinginan konsumennya.

Permasalahan yang utama yang dihadapi oleh UMKM adalah permasalahan keterbatasan modal, baik modal kerja maupun investasi dan kesulitan komunikasi pemasaran (Kadin, 2008: 44). Persaingan pasar yang semakin terbuka menuntut semua pelaku usaha kuliner (Martabak Djoeragan, Mini Chef dan Waroenk Baper) di Kota Pekanbaru mampu beradaptasi dengan perubahan perilaku bisnis yang terjadi bila tidak ingin tergilas atau lenyap sama sekali dari pertarungan pasar. Adanya permasalahan internal dari usaha kuliner serta perkembangan lingkungan dan teknologi yang demikian cepat menyebabkan usaha kuliner kurang mampu mengakses informasi pasar (Indah dan Lestari, 2009: 18). Salah satu langkah yang disarankan untuk dilakukan adalah perluasan pemasaran. Dalam memasarkan produknya, usaha kuliner harus mengetahui cara menganalisis kesempatan pasarnya, cara memilih sasaran yang tepat, dan cara mengelola usaha komunikasi yang efektif dan didukung dengan efektifitas pemasaran. Menurut Etaswara (dalam Hidayata, Utama, 
dan Romadhani, 2011) pemasaran di era informasi ini adalah komunikasi dan komunikasi adalah pemasaran, dimana keduanya tidak pernah bisa dipisahkan.

Dengan adanya fenomena tersebut para pengusaha kuliner (Martabak Djoeragan, Mini Chef dan Waroenk Baper) di kota Pekanbaru dapat memanfaatkan komunikasi pemasaran sebagai alat untuk memperkenalkan kulinernya, meningkatkan pasar dan menjaga kesetiaan para konsumennya, bahkan mempertahankan eksistensi yang di miliki usaha kuliner ini. Penggunaan internet dalam komunikasi pemasaran cukup mendapat perhatian, adapun cara dan modelnya juga bervariasi, mulai dari perancangan web profile, web untuk product service, model pemasaran referall, model pemasaran komunitas melalui situs jejaring sosial dan lain- lain.

Semua model tersebut juga didukung oleh visual dan pengaturan porsi informasi yang ditampilkan. Pemasaran media online mulai populer sejalan dengan makin populernya penggunaan internet. Sebelum adanya pemasaran media online, kegiatan pemasaran membutuhkan biaya yang tidak sedikit. Akibatnya para perusahaan kecil atau yang baru bertumbuh tidak mampu melakukan aktivitas pemasaran secara optimal (Lasmadiarta, 2010:3).

Banyak perusahaan-perusahaan besar seperti WOOW Catering, @PekanbaruCo, dan perusahaan lainnya di kota Pekanbaru memanfaatkan internet (New Media) sebagai fasilitas yang utama dalam memasarkan produk mereka. Hal ini mungkin dapat dicontoh oleh usaha kuliner Martabak Djoeragan, Mini Chef dan Waroenk Baper di kota Pekanbaru. Seperti apa peranan internet (New Media) pada usaha kuliner di kota Pekanbaru nantinya jika diterapkan oleh usaha kuliner Martabak Djoeragan, Mini Chef dan Waroenk Baper itu sendiri.

Jika fenomena manfaat New Media yang sangat baik terasa oleh perusahaan, bisa saja hal yang sama juga di rasakan oleh usaha kuliner Martabak Djoeragan, Mini Chef dan Waroenk Baper di kota Pekanbaru. Dalam hal ini, New Media dapat menjadi nyawa dari komunikasi pemasaran untuk meningkatkan pasar usaha kuliner Martabak Djoeragan, Mini Chef dan Waroenk Baper di kota Pekanbaru. Suatu pemahaman yang mendalam mengenai komunikasi pemasaran dan perencanaan harus diusulkan dengan konsep dan ide kreatif yang baik. Hal ini dilakukan dalam prakteknya agar komunikasi pemasaran yang dilakukan dapat menarik khalayak sebanyak mungkin.

\section{Pengertian Strategi Komunikasi}

Strategi dalam komunikasi berasal dari stratego, yang diambil dari bahasa Yunani. Kata ini merupakan dari strate yang berarti tentara dan ego yang berarti tentara. Sebagaimana yang dinyatakan oleh Andrew (dalam Bryson, 2005:10). Strategi pada 
hakikatnya adalah perencanaan (planning) dan manajemen (management) untuk mencapai suatu tujuan. Namun untuk mencapai tujuan tersebut, strategi tidak berfungsi sebagai peta jalan yang hanya menunjukkan arah saja, tetapi harus menunjukkan bagian taktik operasionalnya (Effendy, 2002:29).

Strategi komunikasi yang merupakan paduan perencanaan komunikasi (communication planning) dengan manajemen komunikasi (communication management) untuk mencapai tujuan yang telah ditetapkan (Effendy, 2005:10). Menurut Sri Mardinah (dalam Effendy, 2005: 11) yang dimaksud dengan strategi komunikasi adalah suatu cara untuk mengatur pelaksanaan proses komunikasi sejak dari perencanaan, pelaksanaan sampai dengan evaluasi untuk mencapai suatu tujuan. Strategi komunikasi bertujuan agar: Pesan mudah dipahami secara benar, Penerima pesan dapat dibina dengan baik, dan Kegiatan dapat termotivasi untuk dilakukan

\section{Komunikasi Pemasaran}

Komunikasi pemasaran diartikan sebagai aplikasi komunikasi yang bertujuan untuk membantu kegiatan pemasaran sebuah perusahaan yang merupakan penggabungan dari lima model komunikasi dalam pemasaran, antara lain periklanan, promosi penjualan, penjualan perseorangan, hubungan masyarakat, dan penjualan langsung agar tujuan perusahaan tercapai, yang terjadinya peningkatan pendapatan atas penggunaan produk atau jasa yang ditawarkan (Soemanegara, 2006).

Menurut Kotler (2002:8) Pemasaran diartikan suatu proses sosial, dimana melalui proses itu individu-individu dan kelompok tersebut memperoleh apa yang mereka butuhkan dan inginkan dengan cara menciptakan serta menawarkan secara bebas atau mempertukarkan produk dan nilai dengan individu dan kelompok lain. Strategi Komunikasi Pemasaran

Pada dasarnya strategi komunikasi pemasaran merupakan keputusan-keputusan dari manajemen tentang elemen-elemen bauran promosi (promotional mix) perusahaan sebab di dalam komunikasi pemasaran secara umum menggunakan bauran promosi. Philip Kotler (dalam Morissan 2010:55-74) mengatakan ada 3 langkah yang harus dilakukan agar komunikasi pemasaran berhasil: Segmentasi, Targeting, dan Positioning.

Segmentasi pada dasarnya adalah suatu strategi untuk memahami struktur konsumen. Segmentasi diperlukan agar perusahaan dapat melayani konsumennya secara lebih baik, melakukan komunikasi yang lebih persuasif dan yang terpenting adalah memuaskan kebutuhan dan keinginan konsumen yang dituju. Untuk memasarkan 
suatu produk, praktisi pemasaran harus tahu siapa yang akan menjadi konsumennya.

Targeting atau menentukan strategi pasar adalah persoalan bagaimana memilih, menyeleksi, dan menjangkau konsumen. Target pasar merupakan memilih satu atau beberapa segmen konsumen yang akan menjadi fokus kegiatan pemasaran dan promosi. Perusahaan harus memiliki keinginan keberanian untuk memfokuskan kegiatannya pada beberapa bagian saja (segmen) konsumen dan meninggalkan bagian lainnya.

\section{Positioning adalah strategi} komunikasi yang berhubungan dengan bagaimana khalayak menempatkan suatu produk, merek atau perusahaan di dalam otaknya, di dalam alam khayalnya, sehingga khalayak memiliki penelitian tertentu. Pengelola pemasaran harus mengetahui bagaimana konsumen memproses informasi, menciptakan persepsi, dan bagaimana konsumen memproses informasi, menciptakan persepsi, dan bagaimana persepsi mempengaruhi pengambilan keputusannya" (dalam Morissan 2010:5574)

Perencanaan strategi pemasaran dan pemilihan target pasar memberikan petunjuk kepada kita mengenai siapa konsumen yang akan menjadi fokus kegiatan pemasaran serta apa kebutuhan mereka yang belum terpuaskan. Untuk itu perusahaan perlu terlebih dahulu mengetahui strategi komunikasi pemasaran yang bagaimana yang perlu mereka lakukan, agar pemasarannya efektif dan tujuan perusahaan tercapai dengan maksimal.

\section{Bauran Pemasaran}

Menurut Darmawan (2004:23), gabungan dari beberapa faktor pemasaran dapat mempengaruhi perilaku konsumen. Bagaimana masing-masing komponen bauran pemasaran dapat mempengaruhi perilaku konsumen, akan diuraikan sebagai berikut: Produk adalah segala sesuatu yang memiliki nilai dan ditawarkan ke pasar untuk memenuhi kebutuhan. Produk berisi seperangkat atribut dan manfaat yang terkandung yang dianggap sangat penting hingga kurang penting menurut pemakainya. Beberapa atribut produk diantaranya: Kualitas produk, merupakan kemampuan produk untuk menjalankan fungsinya, termasuk juga mencakup daya tahan, kehandalan, ketepatan, kemudahan penggunaan, perbaikan serta atribut bernilai lainnya. Fitur produk, mengarah kepada alatalat yang dapat digunakan untuk membedakan produk perusahaan dengan lainnya. Perusahaan yang mampu memperkenalkan fitur baru sesuai kebutuhan konsumen merupakan cara efektif memenangkan persaingan. Desain produk, berbeda dengan gaya. Gaya hanya menggambarkan tampilan produk yang tampak secara fisik. Desain produk bukan 
tentang penampilan saja, tetapi lebih mengarah kepada peningkatan kinerja produk. Harga adalah sejumlah uang yang ditukarkan untuk memperoleh suatu produk. Kepekaan harga dari konsumen sangat menentukan target pasar yang dituju. Segmen tertentu mengedepankan harga dibanding atribut lain, namun segmen yang lain lebih mengutamakan kualitas walaupun harganya cukup tinggi.

Pengenalan produk ke pasar diupayakan melalui promosi. Promosi bukan sekedar periklanan. Bauran promosi terdiri dari: (1) Periklanan, semua bentuk komunikasi non-personal tentang gagasan, barang atau jasa yang dibiayai oleh sponsor tertentu. Periklanan dapat berbentuk iklan cetak, brosur, billboard atau poster. (2) Hubungan masyarakat, merupakan kegiatan promosi yang ditujukan kepada publik untuk mengkomunikasikan citra positif produk atau perusahaannya dan untuk mempromosikan niat baik. Bentuknya dapat dilakukan dengan menjadi sponsor pada peristiwa atau kegiatan-kegiatan tertentu. (3) Promosi penjualan, beragam insentif jangka pendek untuk mendorong keinginan mencoba atau membeli suatu produk atau jasa. Pameran, pembagian voucher, pembagian sampel produk adalah bentuk-bentuk dari promosi penjualan. (4) Penjualan tatap muka, merupakan komunikasi langsung tatap muka antara satu calon pembeli atau lebih dimana mereka memberikan umpan balik segera terhadap sumber pesan dalam bentuk presentasi.

\section{Hubungan antara Strategi dengan Pemasaran}

Strategi pemasaran merupakan hal sangat penting bagi perusahaan di mana strategi pemasaran merupakan suatu cara mencapai tujuan dari sebuah perusahaan. Hal ini juga didukung oleh pendapat Swasta (23: 2014) "Strategi adalah serangkaian rancangan besar yang menggambarkan bagaimana sebuah perusahaan harus beroperasi untuk mencapai tujuannya." Strategi pemasaran tidak hanya diperuntukkan bagi usaha berskala besar saja. Usaha kecil juga membutuhkan strategi pemasaran untuk mengembangkan usahanya, karena sering kali pada saat kondisi kritis justru usaha kecil yang mampu memberikan pertumbuhan terhadap pendapatan masyarakat.

\section{Basis Komunikasi Pemasaran}

Paradigma komunikasi yang selama dianut, yang hanya mementingkan upaya perusahaan memikat konsumen dengan mengandalkan iklan dan promosi semata mulai dipertanyakan banyak pihak. Munculnya berbagai inovasi pada piranti komunikasi, pesan, dan khalayak memaksa perusahaan menoleh pada komunikasi pemasaran terintegrasi (integrated marketing communications-IMC). Menurut four As (the American Association of Advertising 
Agency), IMC adalah konsep perencanaan komunikasi pemasaran yang mengakui nilai tambah dari perencanaan komprehensif yang mengkaji peran strategis masing-masing bentuk komunikasi, misalnya iklan, respons langsung, promosi penjualan, dan humas (hubungan masyarakat), serta memadukannya untuk meraih kejelasan pesan, konsistensi, dan dampak komunikasi maksimal melalui integrasi pesan. Secara singkat komunikasi pemasaran terintegrasi (IMC) adalah menyatukan perencanaan, tindakan dan koordinasi pada semua wilayah komunikasi pemasaran dan juga memahami konsumen menyangkut apa sesungguhnya tanggapan konsumen (Hermawan, 2012: 52).

\section{Komunikasi Pemasaran Melalui Internet}

Menurut Mohammed, Fisher, Jaworski, dan Paddison (2003: 104), terdapat lima komponen dalam internet marketing, yaitu: (1) Proses, (2) Membangun dan mempertahankan hubungan dengan pelanggan, (3) Online, (4) Pertukaran, (5) Pemenuhan kepuasan kebutuhan kedua belah pihak.

\section{Definisi UMKM}

Usaha Mikro Kecil Menengah (UMKM) memiliki definisi berbeda-beda yang dikeluarkan oleh beberapa instansi pemerintah. Agar penjelasan mengenai UMKM dapat lebih dimengerti, maka berikut ini beberapa definisi UMKM (dalam Murpi, 2012: 1-3): (1) Kementrian Negara
Koperasi dan Usaha Kecil Menengah, Usaha Kecil (termasuk Mikro) merupakan entitas usaha yang memiliki kekayaan bersih paling banyak Rp. 200.000.000. (2) Badan Pusat Statistik (BPS) memberikan definisi UMKM berdasarkan kuantitas tenaga kerja. Usaha Kecil merupakan entitas usaha yang memiliki jumlah tenaga kerja 5 hingga 19 orang, sedangkan usaha menengah merupakan entitas usaha yang memiliki tenaga kerja 20 hingga 99 orang. (3) Menurut keputusan Menteri Keuangan Nomor 316/ KMK.016/ 1994, pada tanggal 27 Juni 1994, usaha kecil didefinisikan sebagai perorangan atau badan usaha yang telah melakukan kegiatan, dengan penjualan tahun setinggi-tingginya Rp. 600.000 .000 atau aset/ aktivitas setinggi-tingginya Rp. 600.000 .000 (di luar tanah dan bangunan yang ditempati. (4) Pada tanggal 4 Juli 2008 telah ditetapkan Undang-undang No. 20 Tahun 2008 tentang Usaha Mikro, Kecil dan Menengah. Definisi UMKM yang disampaikan oleh Undang-undang ini juga berbeda dengan definisi di atas. Menurut UU No 20 Tahun 2008.

\section{Konsumen}

Menurut Kotler (2005) konsumen adalah jumlah atribut dari produk atau jasa. Veloutsu (2005:46) dalam penelitian menjelaskan mengenai produk, ada perbedaan antara kepuasan konsumen barang dan jasa. Perbedaan antara barang berwujud 
dan tidak berwujud menjadi berbagai factor kepuasan konsumen, dan itulah sebabnya mereka harus diperlakukan terpisah dan berbeda Churcil (2002:36). Kepuasan konsumen memiliki reaksi secara keseluruhan antara harapan konsumsi dengan produk atau jasa di pasar persepsi reaksi, evaluasi dan psikologis (Kurniawan, 2010:48).

\section{Kerangka Pemikiran}

Komunikasi pemasaran yang baik dalam pelaksanaannya akan berdampak pada persepsi positif (kepercayaan) terhadap merek yang disampaikan, begitu juga sebaliknya kepercayaan merek akan memperlancar komunikasi pemasaran terintegrasi. Berikut model IMC Takada, $\mathrm{H}$. Chattalas, C., Kramer, T (dalam Hermawan, 2012: 55):

\section{Model Komunikasi Pemasaran Terintegrasi (IMC)}

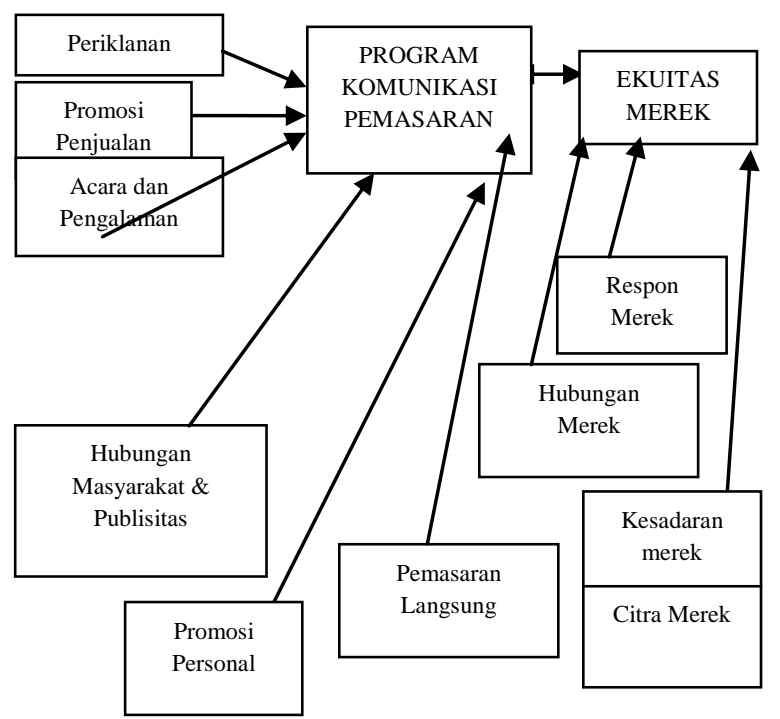

Sumber: Hermawan, 2012: 55.
Dari model tersebut dapat menghasilkan model kerangka penelitian, seperti dibawah:

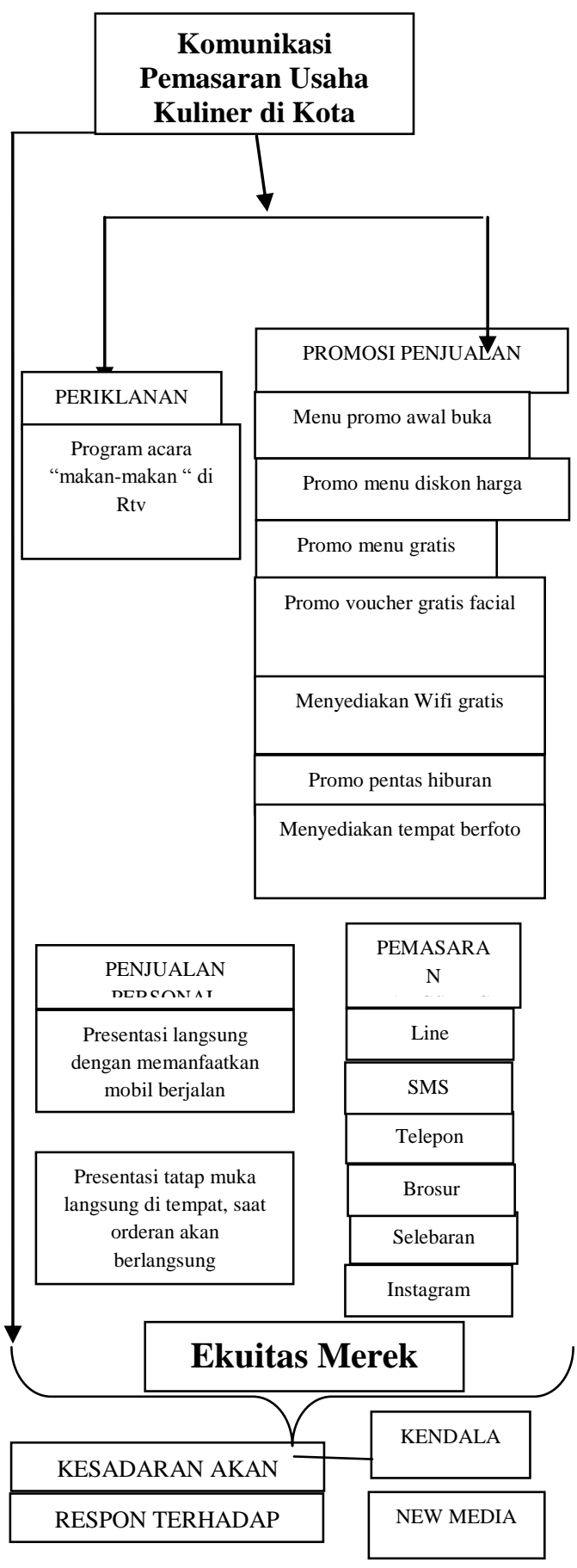

Sumber: Olahan Peneliti, 2017

\section{METODE}

Metode yang dipakai dalam penelitian ini adalah metode penelitian kualitatif. Pada penelitian ini yang menjadi Informan adalah 
individu yang terlibat dalam pelaksanaan UMKM kuliner. Peneliti telah memilih tiga usaha kuliner yakni Martabak Djoeragan, Mini Chef dan Waroenk Baper yang mana ketiga usaha kuliner ini merupakan usaha kuliner yang termasuk menjadi trending topic oleh para masyarakat Kota Pekanbaru pada masanya masing-masing. Selain itu ketiga usaha kuliner ini merupakan usaha kuliner yang memiliki tujuan berbeda masing-masing yakni untuk mengenalkan, mengembangkan dan mempertahankan.

Dalam hal ini yang menjadi informan dari ketiga usaha kuliner ini adalah pemilik usaha kuliner Martabak Djoeragan yaitu Bapak Rizki, pemilik usaha Mini Chef yakni Ibu Ayu, leader usaha Waroenk Baper Pekanbaru yaitu Mas Heri, dan informan selanjutnya yakni Dinas Koperasi UMKM Kota Pekanbaru sebagai Dinas terkait yang bertugas untuk mengelola dan mengawasi UMKM di Kota Pekanbaru termasuk usaha kuliner. Adapun yang dijadikan informan oleh peneliti di Dinas Koperasi UMKM Kota Pekanbaru yaitu Bapak Drs. Zainuddin sebagai Kepala Bagian Umum, serta 14 konsumen yang terdiri dari enam orang konsumen usaha kuliner Martabak Djoeragan, lima orang konsumen usaha kuliner Mini Chef dan tiga orang konsumen usaha kuliner Waroenk Baper. Adapun yang menjadi informan diteliti dengan menggunakan metode Purposive Sampling. Penelitian ini menggunakan teknik pengumpulan data antara lain, yakni: wawancara, observasi dan dokumentasi. Dalam penelitian ini peneliti menggunakan teknik analisis data yang dipopulerkan oleh Huberman dan Miles yaitu model analis data interaktif. Sedangkan pada teknik keabsahan data peneliti menggunakan perpanjangan keikutsertaan dan triangulasi. Lokasi penelitian berada di kota Pekanbaru dari bulan Mei 2016 sampai Maret 2017.

\section{HASIL DAN PEMBAHASAN}

\section{Komunikasi Pemasaran Usaha di Kota}

Pekanbaru Melalui Kegiatan Periklanan

Martabak Djoeragan merupakan usaha kuliner yang cukup lama sudah berdiri di Kota Pekanbaru. Usaha kulinernya memanjakan lidah pecinta martabak. Saat pertama kali muncul di Kota Pekanbaru Martabak Djoeragan menggunakan iklan sebagai pengenalan kepada masyarakat bahwasanya telah hadir usaha kuliner yang mempunyai rasa yang memanjakan lidah, lengkap dengan toping yang bermacammacam serta outlet yang berkonsep.

Iklan yang digunakan oleh Martabak Djoeragan bukan iklan biasa namun iklannya berupa liputan kuliner yang tergabung dalam program acara "Makan-Makan" di RTV. Dalam kegiatan komunikasi pemasaran menggunakan periklanan ini, pihak usaha kuliner Mini Chef mengaku tidak pernah melakukan promosi menggunakan iklan. Menurut pihak Mini Chef jika ingin 
menggunakan iklan harus ada budget tertentu yang terbilang cukup menguras kantong, sedangkan owner Mini Chef ini merupakan pemain baru di bidang usaha kuliner. Dengan adanya hal tersebut pihak Mini Chef tidak mau mengambil resiko yang mana nantinya jika sudah di iklankan namun tidak mendapat feed back yang baik ke Mini Chef maka akan menimbulkan kerugian sendiri kepada pihak Mini Chef.

Menurut pihak usaha kuliner Waroenk Baper mengungkapkan mereka belum melakukan komunikasi pemasaran melalui periklanan. Walaupun pihak Waroenk Baper Pekanbaru masih terbilang baru mereka masih belum berniat untuk menggunakan periklanan sebagai salah satu program komunikasi pemasarannya. Menurut mereka untuk saat ini mereka masih belum membutuhkan iklan sebagai promosi pengenalan usaha kuliner pihak Waroenk Baper Pekanbaru, karena penggunaan iklan juga harus mengeluarkan biaya yang terbilang cukup besar.

\section{Komunikasi Pemasaran Usaha Kuliner di}

\section{Kota Pekanbaru Melalui Kegiatan Promosi}

\section{Penjualan}

Bentuk-bentuk kegiatan promosi penjualan yang dilakukan usaha kuliner Martabak Djoergana, Mini Chef dan Waroenk Baper Pekanbaru meliputi: adanya promo menu-menu terbaru yang unik dengan tampilan menarik serta berbagai macam menu spesial dengan potongan harga di hari-hari besar, harga murah meriah di awal menu muncul dan memberikan voucher gratis untuk facial gratis namun dengan syarat yang sudah ditentukan pihak usaha kuliner.

Tidak hanya itu usaha kuliner juga memberikan bonus menu kepada konsumen sesuai dengan ketentuan usaha kuliner ini. Kemudian ada juga usaha kuliner yang mengadakan kuis-kuis berhadiah yang mana nantinya pemenang akan mendapatkan menu gratis. Pada dasaranya promosi penjualan yang dilakukan oleh usaha kuliner Martabak Djoeragan, Mini Chef dan Waroenk Baper Pekanbaru berbeda-beda antara satu sama lain.

\section{Komunikasi Pemasaran Usaha Kuliner di}

Kota Pekanbaru Melalui Kegiatan

\section{Publisitas dan Hubungan Masyarakat}

Poin pertama dapat dilihat dari pernyataan owner Martabak Djoeragan ia mengungkapkan dulunya sempat pernah mempublish usaha kulinernya melalui program acar "Makan-Makan" yang di siarkan di RTV, namun hal itu hanya dilakukan sekali saat awal mula membuka cabang di Kota Pekanbaru. Sedangkan untuk saat ini publish yang sedang berjalan dan dilakukan oleh pihak Martabak Djoeragan ialah dengan memaparkan logo di mobil berjalan yang dipunyai oleh Martabak Djoeragan. Kegiatan hubungan masyarakat dilakukan dengan tatap muka langsung dengan memberikan pelayanan yang terbaik serta ramah tamah saat menangani pelanggannya. Tidak hanya itu para karyawan Martabak Djoeragn juga melakukan atraksi menarik saat 
membuat pesanan Martabak Djoeragan untuk para konsumennya.

Berbeda halnya publisitas dan hubungan masyarakat yang dilakukan oleh pihak Martabak Djoeragan yang lebih bervariatif, usaha kuliner Mini Chef hanya melakukan publisitas melalui instagram KulinerPKU untuk mempublish kuliner yang dijalankannya, sedangkan hubungan masyarakat yang dilakukan pihak Mini Chef yakni memberikan pelayanan yang baik, murah memberikan senyuman, mengusahakan pesanan tidak lama datang ke meja konsumen, dan terakhir menampung saran dari pada konsumen baik mengenai rasa menu, pelayanan dan hal-hal lain yang membuat pihak Mini Chef semakin baik kedepannya sehingga dapat memuaskan konsumennya.

Hal yang sama juga dilakukan oleh pihak Waroenk Baper Pekanbaru melalui kegiatan publisitas dan hubungan masyarakat dengan memanfaatkan instagram dan di bantu oleh akun instagram dealpku yang mana menjadi referensi para masyarakat untuk melihat tempat kuliner yang rekomended. Selain itu pihak Waroenk Baper Pekanbaru juga melakukan hubungan masyarakat yang hampir sama dengan yang dilakukan usaha kuliner Mini Chef yakni dengan tatap muka selalu berusaha memberikan pelayanan yang terbaik untuk para konsumennya.
Komunikasi Pemasaran Usaha Kuliner di Kota Pekanbaru Melalui Kegiatan

Penjualan Personal (Personal Selling)

Kegiatan personal selling yang dilakukan usaha kuliner Martabak Djoeragan yaitu dengan cara menjelaskan ataupun presentasi di hadapan calon konsumen. Presentasi merupakan salah satu bentuk strategi yang baik karena dapat membangun hubungan yang lebih erat dengan calon konsumen karena komunikasi bisa dilakukan dengan dua arah dan interaktif serta memperoleh tanggapan dengan lebih cepat sehingga akan membuat masyarakat Kota Pekanbaru lebih mengenal Martabak Djeoragan sehingga konsumen semakin ramai. Pihak Mini Chef melakukan penjualan personal dengan mempresentasikan menumenu yang ditanyakan konsumen saat ingin memesan dan mengetahui menu yang disiapkan Mini Chef. Usaha kuliner Waroenk Baper juga melakukan penjualan personal dengan memberikan presentasi berupa penjelasan menu-menu yang disajikan, berbagai cita rasa dan berusaha memberikan gambaran foto di buku menu mengenai bentuk tampilan menunya, serta pihak Waroenk Baper Pekanbaru memberikan waktu untuk berpikir kepada konsumen mengenai menu yang mana akan di pesannya.

\section{Komunikasi Pemasaran Usaha Kuliner di Kota Pekanbaru Melalui Kegiatan Pemasaran Langsung}

Pihak Martabak Djoeragan melakukan pemasaran langsung mulai dari menggunakan 
Line, SMS, dan juga melalui telepon serta membagikan brosur opening cabang outlet melalui facebook dan instagram. Terkhusus untuk pelayanan telepon atau pengaduan melalui telepon pihak Martabak Djoeragan memberikan nomer telepon leader masingmasing cabang. Ada beberapa kegiatan pemasaran langsung yang dilakukan pihak Mini Chef, antara lain dalam bentuk SMS, Telepon, melalui instagram Mini Chef dan juga melalui brosur. Waroenk Baper Pekanbaru memang sempat menggunakan selebaran sebagai alat untuk mengenalkan usaha kulinernya.

Namun saat ini pihak Waroenk Baper lebih memilih penggunaan instagram sebagai alat untuk memasarkan langsung kepada para konsumen dengan membagikan foto berbagai menu dan foto suasana tempatnya. Selain itu banyak para konsumen yang ikut membagikan foto momen mereka di saat berada di Waroenk Baper Pekanbaru melalui instagram pihak Waroenk Baper Pekanbaru. Para konsumen dan pihak Waroenk Baper Pekanbaru juga sering melakukan interaktif dengan berbalas komentar.

\section{Komunikasi Pemasaran Usaha Kuliner di}

\section{Kota Pekanbaru Melalui Kegiatan Acara dan pengalaman}

Dalam hal komunikasi pemasaran usaha kuliner (Martabak Djoeragan, Mini Chef dan Waroenk Baper Pekanbaru) di Kota Pekanbaru melalu kegiatan acara dan pengalaman ini hanya dilakukan oleh usaha kuliner Martabak Djoeragan. Yang mana usaha kuliner Martabak Djoeragan merupakan usaha kuliner yang lebih dulu terjun ke dunia usaha kuliner, sedangkan pihak usaha kuliner Mini Chef yang masih tergolong belum lama dan usaha kuliner Waroenk Baper yang baru saja berdiri beberapa bulan terakhir sampai saat ini belum melakukan komunikasi pemasaran melalui kegiatan acara dan pengalaman.

\section{Komunikasi Pemasaran Usaha Kuliner}

(Martabak Djoeragan, Mini Chef dan

\section{Waroenk Baper) di Kota Pekanbaru}

\section{Terkait Dengan Ekuitas Merek}

Dalam pembentukan equitas merek ini dapat dilihat melalui beberapa aspek penting. Antara lain dapat dilihat melalui kesadaran akan merek dan respon terhadap merek. Hal ini juga dilihat oleh penulis dari usaha kuliner Martabak Djoeragan, Mini Chef dan Waroenk Baper. Penulis tidak hanya sekedar melihat program komunikasi pemasaran yang dilakukan masing-masing usaha kuliner tersebut tetapi juga mengaitkan dengan terbentuknya equitas merek dilihat dari kesadaran akan merek dan respon terhadap merek hubungan dengan merek.

Peranan New Media pada usaha kuliner (Martabak Djoeragan, Mini Chef dan Waroenk Baper) di Kota Pekanbaru

Pemasaran yang menggunakan New Media sebagai saluran penyampaian isi pemasaran, inilah yang kemudian disebut sebagai saluran penyampaian isi pemasaran inilah yang kemudian disebut sebagai pemasaran melalui Internet bukanlah upaya 
pemasaran yang menjual penyedia layanan (hubungan/koneksi) Internet (Hermawan, 2012: 206-207). Untuk mengikuti perkembangan zaman tiga usaha kuliner ini yakni usaha kuliner Martabak Djoeragan, Mini Chef dan Martabak Djoeragan juga melakukan komunikasi pemasaran melalui New Media. Bahkan menurut ke tiga usaha kuliner ini, komunikasi pemasaran melalui New Media sangat efektif di lakukan untuk mencapai sasaran targetnya.

Selain itu ke tiga usaha kuliner ini juga dapat memanfaatkan New Media sebagai media pengenalan yang lebih mendalam kepada masyarakat tentang usaha kulinernya. Hal lain yang dapat dilakukan ketiga usaha ini adalah memberitahukan menu baru yang dilemparkan ke sosial media, sehingga konsumen dapat langsung merespon.

\section{KESIMPULAN}

Komunikasi pemasaran dalam usaha kuliner di kota Pekanbaru sangat membutuhkan yang namanya komunikasi pemasaran tanpa adanya komunikasi pemasaran usaha kuliner yang sudah lama berkembang, akan berkembang dan yang akan mengenalkan usahanya tidak dapat mencapai sasaran target kepada konsumennya. Seain itu usaha kuliner juga harus melakukan komunikasi pemasaran yang tepat, misalnya dengan menggunakan New Media sebagai saluran utama untuk melakukan komunikasi pemasarannya. Dengan hal ini tiga owner dari masing-masing usaha kuliner ini akan dapat menyampaikan informasi yang tepat dan jelas kepada masyarakat kota Pekanbaru. Hal lain yang harus di perhatikan oleh usaha kuliner ini adalah mengenai ekuitas merek, yang mana sangat berdampak kepada kepercayaan masyarakat terhadap pilihan kuliner masyarakat.

\section{DAFTAR PUSTAKA}

Aaker, J. L. (2000). Dimensions of Brand Personality. Journal of Marketing Research, 34(3).

Abdurrahman, N. H. (2015). Manajemen Strategi Pemasaran. Bandung: Pustaka Setia.

Alwasilah. (2002). Metode Penelitian Kualitatif. Jakarta: Remaja Rosdakarya.

Amstrong, G. (2004). Pemasaran Edisi Kesembilan. Jakarta: Indeks Kelompok Gramedia.

Angiopora, M. P. (2005). Sinergi Komunikasi Pemasaran. Jakarta: Mizan Pustaka.

Bryson. (2005). Strategi Komunikasi. Jakarta: Erlangga.

Bungin, B. (2004). Penelitian Kualitatif Komunikasi. Jakarta: Kencana.

Bungin, B. (2007). Penelitian Kualitatif Komunikasi, Ekonomi, Kebijakan Publik, dan Ilmu Sosial Lainnya. Jakarta: Kencana.

Darmawan. (2004). Taktik \& Strategi. Jakarta: PT Buana Ilmu Populer.

Dina \& Purtanto, A. (2013). Strategi komunikasi pemasaran melalui event dalam pembentukan brand equity "Studi Deskriptif Strategi Komunikasi Pemasaran Melalui Event Pocari Sweat Futsal Championship 2013 (PSFC 2013) Regional Yogyakarta dalam Pembentukan Brand Equity Pocari Sweat Pada YGO Event Management. Jurnal Universitas Atmajaya Yogyakarta. e-journal.uajy.ac.id.

Effendi, O. U. (2007). Ilmu Komunikasi Teori dan Praktek. Bandung: Remaja Rosdakarya.

Eriyanto. (2004). Konsep Kajian Komunikasi. Bandung: Remaja Rosdakarya. 
Febriani. M. (2014). Strategi Komunikasi Pemasaran@Pekanbaruco dalam Membangun Brand Image. Skripsi Universitas Riau.

Fill, C. (2005). Marketing Communication: Context, Content, and Strategic 2 edition. Canada: Mc Graw Hil.

Hermawan, A. (2012). Komunikasi Pemasaran. Jakarta: Erlangga.

Indra \& Lestari, S. (2009). Kajian Efektifitas Model Promosi Pemasaran Produk Usaha Mikro Kecil dan Menengah (UMKM). Jurnal Pengkajian Koperasi dan UKM, 4, 116-139.

Integrated Communications. Thomson South-Western:Ohio.

Kadin. (2008). Manajemen Strategi Pemasaran. Bandung: Pustaka Setia

Kartajaya, H. (2010). Perjalan Pemikiran Konsep Pemasaran. Surabaya: Penerbit Erlangga.

Kenedy, J. E. (2006). Marketing Communication. Jakarta: PT. Bhuana Ilmu Populer.

Kick, M. (2005). The Marketing Communication Proses. Tokyo: Mc. Graw Hill Kagakusha, Ltd.

Kotler, P. \& Amstrong, G. (2002). DasarDasar Pemasaran Edisi Kesembilan. Jakarta: Indeks Kelompok Gramedia.

Kotler, P. \& Amstrong, G. (2004). PrinsipPrinsip Pemasaran. Jakarta. Erlangga.

Kotler, P. \& Keller, K. L. (2009). Marketing Management, 13th Ed. Upper Saddle River, NJ: Pearson Education, Inc.

Kotler, P. (2007). Principles of Marketing. 11 Edition. New Jersey: Prentice Hall.

Kotler, P. (2008). Manajemen Pemasaran, Jilid 1 dan 2. Jakarta: PT. Indeks Kelompok Gramedia.

Kriyantono, R. (2009). Teknik Praktis Komunikasi. Edisi Pertama. Jakarta: Kencana Media Group.

Lilly, F. H. (2013). Strategi Komunikasi Pemasaran Batik (Studi Kasus Strategi Komunikasi Pemasaran Terpadu Batik Dwi Hadi Surakarta). Jurnal Naskah Publikasi Universitas Muhammadiyah Surakarta. eprints.ums.ac.id

Lutfi, G. (2014). Strategi Komunikasi Pemasaran Warung Pasta. Jurnal Telkom University.
Moleong, L. J. (2005). Metodologi Kualitatif Edisi Revisi. Bandung: Remaja Rosdakarya.

Moleong, L. J. (2013). Metodologi Kualitatif EdisiRevisi. Bandung: Remaja Rosdakarya.

Morissan. (2010). Pemasaran Ritel. Jakarta: Gramedia Pustaka Utama.

Muhamad. (2009). Metode Penelitian. Bandung: Remaja Rosdakarya.

Murpi, S. (2012). Business Plan Praktis dan Dahsyat untuk UMKM. Jakarta: Laskar Aksara.

Nasution, S. (2008). Metode Research, Jakarta: Bumi Aksara.

Poerwandari, E. K. (2009). Pendekatan Kualitatif dalam Penelitian Psikologi. Jakarta: LPSP3 UI Jakarta.

Rangkuti, F. (2002). Creating Efektif Marketing Plan. Jakarta. Gramedia Pustaka Utama.

Ridwan. (2004). Metode Kualitatif. Jakarta: Remaja Rosdakarya.

Shimp, A. T. (2003). Advertising And Promotion\& Supplemental Aspects Of

Sistaningrum, W. (2002). Manajemen Penjualan Produk. Jakarta: Kanisius.

Soemanegara, Rd. (2008). Strategic Marketing Communication. Konsep Strategis dan Terapan. Bandung: Alfabeta.

Sugiyono. (2011). Statistika untuk Penelitian. Bandung: Alfabeta.

Sugiyono. (2012). Statistika untuk Penelitian. Bandung: Alfabeta.

Suriasumantri. (2002). Metode Penelitian. Jakarta: Remaja Rosdakarya.

Sutisna. (2002). Perilaku Konsumen dan Komunikasi Pemasaran. Bandung: Remaja Rosdakarya.

Swasta, B. (2014). Manajemen Penjualan Edisi Ketiga. Yogyakarta: Andi Offset.

Tjiptono, F. (2005). Brand Management \& Strategy. Yogyakarta: Penerbit Andi Offset.

Tjiptono, F. (2012). Strategi Pemasaran. Yogyakarta: Bandung Remaja.

Zaki, S. (2008). Dasar Pemasaran. Edisi Kedua. Jakarta: Raja Grafindo Persada. 